
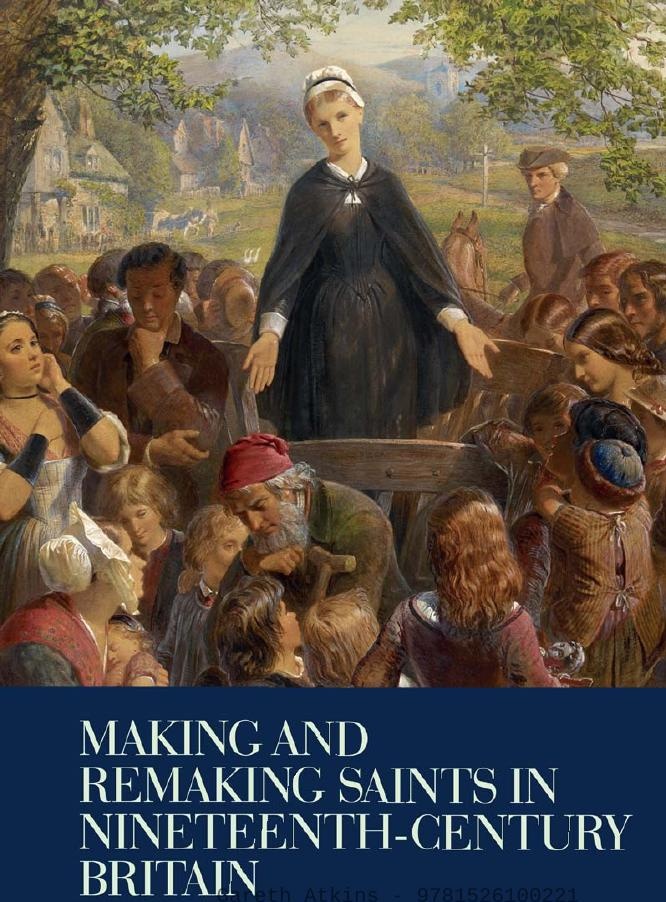

EDITED BY GARETH ATKINS 
Making and remaking saints in nineteenth-century Britain

\section{MANCHESTER 1824}

Manchester University Press 
Gareth Atkins - 9781526100221 


\title{
Making and remaking saints in nineteenth-century Britain
}

\author{
Edited by Gareth Atkins
}

Manchester University Press 
While copyright in the volume as a whole is vested in Manchester University Press, copyright in individual chapters belongs to their respective authors, and no chapter may be reproduced wholly or in part without the express permission in writing of both author and publisher.

Published by Manchester University Press

Altrincham Street, Manchester M1 7JA

www.manchesteruniversitypress.co.uk

British Library Cataloguing-in-Publication Data

A catalogue record for this book is available from the British Library

Library of Congress Cataloging-in-Publication Data applied for

ISBN 9780719096860 hardback

First published 2016

The publisher has no responsibility for the persistence or accuracy of URLs for any external or third-party internet websites referred to in this book, and does not guarantee that any content on such websites is, or will remain, accurate or appropriate.

Typeset in Perpetua by

Servis Filmsetting Ltd, Stockport, Cheshire 